Ann. Génét. Sél. anim., I972, 4 (2), 27I-279.

\title{
HIGH DENSITY DIETS FOR DWARF LAYERS ( $\left.{ }^{1}\right)$
}

\author{
J. H. QUISENBERRY $\left({ }^{2}\right)\left({ }^{3}\right)$ \\ Texas $A$ and $M$ University, Department of Poultry Science \\ College Station, Texas U. S. A. 77843
}

\section{SUMMARY}

The recent widespread introduction of a simply inherited, sex-linked gene for a dwarf bird into the test programs of a number of commercial breeders has focused attention on body size as a potential breakthrough for increasing the feed to food protein conversion of commercial poultry. Evidence from previous experiments at Texas $A$ and $M$ University had suggested that dwarf layers may require a diet with higher nutrient density than their non-dwarf sisters. In an experiment involving non-dwarf birds divided into three weight classes, light, medium and heavy, at 20 weeks of age, the small bodied birds responded more to a higher nutrient density of their diets than the heavier birds. A further suggestion as to the importance of feeding light bodied birds differently from those above a minimum threshold weight, I 300 grams, had been obtained previously from experiments comparing performance of spring versus fall hatched birds in a warm climate and also from the First and Second Texas Gene-Environment Performance Tests.

Two experiments comparing the laying performance of dwarf and non-dwarf birds have been completed. In the first experiment, two diets ( 16 and $17 \mathrm{p}$. Ioo protein) with the same calorie/protein ratio and one, two and three birds per $25.4 \times 45.7 \mathrm{~cm}$ cages were compared. The protein level had little effect on body weight and hen-day egg production of the dwarf layers, but egg size, percentage large eggs and feed efficiency were increased by the higher protein level. The non-dwarf birds decreased in egg production as bird numbers per cage increased, whereas the dwarf birds laid more eggs when housed two birds per cage.

In the second experiment, protein/calorie (p. 1oo/cal $\mathrm{kg}$ P. E.) levels of $22 / 2 \mathrm{r}_{45}, 17 / 2035$, I6/1 980 and $14 / 1925$ were compared. A significant improvement in egg production and feed efficiency of dwarfs receiving the $22 \mathrm{p}$. Ioo protein diet was observed. Livability of the dwarf birds decreased as the protein level decreased, but increased for the non-dwarf birds. When all protein levels were combined, the ratio of performance of the dwarfs versus the non-dwarfs was : body weight, 70 p. 10o ; egg production, 80 p. Ioo ; egg size, 90 p. Ioo ; daily food consumption, 75 p. Ioo; feed efficiency, 95 p. Ioo and livability, 98 p. Ioo.

These results indicate that the dwarf birds need a higher density diet than currently popular non-dwarf lines. Additional testing must be done to determine the optimum nutrient balance for this dwarf-type bird if it is to be widely adopted for commercial laying operation.

(1) Presented to the Symposium on the Dwarf Gene in Domestic Fowl, Tours, France, March 4 and 5, 1971, under the auspices of the Station de Recherches avicoles, Nouzilly, Institut national de la Recherche agronomique.

$\left({ }^{2}\right)$ English summary of this paper has been printed in World's Poultry Sci. J., r971, 27, the french summary has been printed in the present Journal 3. ledged.

$\left({ }^{3}\right)$ The assistance of John W. BRADLEY, Bill H. Doran and John C. Fowler is gratefully acknow- 


\section{INTRODUCTION}

The nutrient requirements for growth, maintenance and egg production differ significantly. Therefore the optimum laying diet for the most efficient production of eggs differs from time to time and becomes a compromise between these three requirements. To complicate the requirements further, there exist significant interactions between these three variables. Of the 36 kilograms of feed consumed by the typical layer per year, 23 are used for growth and maintenance and less than 13 for the production of eggs. Since feed constitutes from three-fifths to two-thirds of the total cost of egg production, breeders and egg producers are currently giving much attention to minimal body weights required for optimal performance.

Breeders have lowered the average body weight of their layers 400 to 500 grams during the past five years, reducing the feed for maintenance by approximately 4.5 kilograms. Their success, in cooperation with the nutritionist, has made the modern laying hen the most efficient converter of feed to food protein the world has ever known. As the adult body weight for laying strains is reduced, new diets of higher nutrient density, more accurate balance and greater palatability must be provided.

\section{DWARFS}

The recent widespread introduction of a simply inherited gene $d w$ for a dwarf bird (HUT', I959) into the test programs of a number of commercial breeders has focused attention on body size as a potential breakthrough for increasing the feed to food protein conversion of commercial poultry. A growing world population and potential competition with plant protein fortified with synthetic amino acids are only two of many factors that justify exploration of this potential tool for further reduction in the cost of producing poultry meat and eggs.

Evidence that small bodied birds responded to a higher nutrient density of their diets than heavier birds of the same strain or cross came from an experiment involving normal, or non-dwarf birds, that were divided into three weight classes, light, medium and heavy, at 20 weeks of age and phase fed different protein levels. Results of this experiment are given in table $I$.

The data in table I suggest that the beneficial effects of phase feeding were mostly limited to the light-weight birds. A further suggestion as to the importance of feeding light bodied birds differently from those above a minimum threshold weight had been obtained previously from experiments comparing performance of spring versus fall-hatched birds in a warm climate and are also contained in table 2 from the First and Second Texas Gene-Environment Performance Tests.

The data in table 2 suggest that diets should be formulated for each weight class, particularly the lights, and although not shown in this table each entrant might benefit from specific formulations. This is particularly true for summer grown pullets in warm climates. 
TABLE I

Performance levels of birds separated according to initial body weight at housing for egg production and either fed a constant protein level $(16 \mathrm{p} .100)$ or phase fed 18 and 16 p. 100 protein

Niveaux de performance des oiseaux classés suivant leur poids corporel initial à la mise en poulaillers de ponte et recevant un aliment à taux protéique constant $(16 p .100)$ ou à 18 et 16 p. 100 de protéines en "phase feeding"

\begin{tabular}{|c|c|c|c|c|}
\hline \multirow{3}{*}{$\begin{array}{c}\text { Housing } \\
\text { wt } \mathrm{kg} / 20 \text { wks }\end{array}$} & \multicolumn{4}{|c|}{ Hen-day egg production $12 / 28$-days } \\
\hline & \multicolumn{2}{|c|}{ Periods 1-6 } & \multicolumn{2}{|c|}{ Periods $7-12$} \\
\hline & Phase & Constant & Phase & Constant \\
\hline 1.1884 & 69.6 & 63.4 & 68.3 & 62.8 \\
\hline 1.3245 & 70.9 & 71.0 & 64.6 & 65.0 \\
\hline 1.4606 & 75.9 & 74.9 & 65.8 & 67.1 \\
\hline
\end{tabular}

TABLE 2

Performance of entries in the First and Second Texas Gene-Environment Performance Tests, $1968-69$ and 1969-70

Performances des entrées dans le premier et le second test de performance "gène-environnement " du Texas, 1968-69 et 1969-70

\begin{tabular}{|c|c|c|c|c|c|c|c|c|c|c|}
\hline \multirow{2}{*}{$\begin{array}{l}\text { Weight } \\
\text { class }(\mathbf{1})\end{array}$} & \multicolumn{2}{|c|}{$\begin{array}{l}\text { Av. initial } \\
\text { Wt. (kg) }\end{array}$} & \multicolumn{2}{|c|}{$\begin{array}{l}\text { Av. final } \\
\text { Wt. (kg) }\end{array}$} & \multicolumn{2}{|c|}{$\begin{array}{c}\text { Hen-day } \\
\text { production } \\
(\%)\end{array}$} & \multicolumn{2}{|c|}{$\begin{array}{c}\text { Egg size } \\
\text { (g) }\end{array}$} & \multicolumn{2}{|c|}{$\begin{array}{c}\text { F. E. } \\
(\mathrm{kg} / \mathrm{kg})\end{array}$} \\
\hline & $1 \mathrm{st}$ & 2nd & $1 \mathrm{st}$ & $2 \mathrm{nd}$ & $1 \mathrm{st}$ & $2 n d$ & $1 \mathrm{st}$ & 2nd & $1 \mathrm{st}$ & 2nd \\
\hline Light & 1.13 & 1.15 & 1.69 & 1.73 & 63.0 & 61.4 & 57.96 & 56.51 & 2.64 & 2.84 \\
\hline Medium . & 1.26 & 1.26 & 1.85 & 1.85 & 64.6 & 62.8 & 59.25 & 57.91 & 2.64 & 2.80 \\
\hline Heavy ... & 1.40 & 1.39 & 2.02 & 2.06 & 65.5 & 63.4 & 60.28 & 58.79 & 2.70 & 2.91 \\
\hline
\end{tabular}

( $\left.{ }^{1}\right)$ Each entry was arrayed by weight and lowest third went into the Light Class, the middle third went into the Medium Class and the top third went into the Heavy Class.

\section{Flock Replacement Costs for Dwarfs Versus Non-dwarfs}

On a per bird basis, dwarf birds would require less housing and equipment space than larger or heavier birds. More significant, would be the savings on feed. Differences in feed to 20 weeks of age for one group of birds hatched in early November are given in table 3. Birds in the latter experiment are currently only slightly more than I2 weeks of age. Time did not permit summarizing the data beyond 8 weeks. Space requirements for dwarf pullets are generally considered to be from one-half to two-thirds that of non-dwarf birds. 
TABLE 3

Body weights and Growing Feed Requirements of Dwarf Versus Non-Dwarf Pullets Poids corporels et besoins alimentaires de croissance des poulettes naines comparées aux non-naines

\begin{tabular}{c|c|c|c|c|c|c|c|c}
\hline \hline & & \multicolumn{2}{|c|}{ Body weight (g) } & \multicolumn{2}{|c}{ Feed consumption (kg) } \\
$\begin{array}{c}\text { Expt. } \\
\text { no. }\end{array}$ & $\begin{array}{c}\text { Age of } \\
\text { pullets }\end{array}$ & $\begin{array}{c}\text { Date of } \\
\text { hatch }\end{array}$ & $\begin{array}{c}\text { Non- } \\
\text { dwarf }\end{array}$ & Dwarf & $\%$ & $\begin{array}{c}\text { Non- } \\
\text { dwarf }\end{array}$ & Dwarf & $\%$ \\
\hline & & & & & & & & \\
1 & 20 wks & Nov. 13 & 1420 & 925 & 65.2 & 7.83 & 6.04 & 77.2 \\
2 & 8 wks & Dec. 31 & 635 & 395 & 62.1 & 2.06 & 1.38 & 67.0 \\
\hline
\end{tabular}

Body weights of these particular types of dwarfs averaged approximately 60-65 p. roo of the non-dwarfs. For the birds in Experiment I approximately I. 8 kilograms of feed were saved to 20 weeks. Perhaps more could have been saved had the dwarfs been raised at a higher density. If the present ratio continues for Experiment 2, the saving in feed will be 5 to ro p. Ioo more than for Experiment I.

\section{Comparison of Laying Performance \\ Dwarfs and Non-dwarfs - Three Experiments}

\section{Experiment 1.}

At the time Experiment I was conducted there was a limited number of dwarf birds available and this experiment was conducted to obtain some basic comparative biological data for the dwarf versus non-dwarf birds from which they had been extracted. Two diets (I6 and I7 p. Ioo protein) with the same protein/calorie ratio and one, two and three birds per $25.4 \times 45.7 \mathrm{~cm}$ cages were compared. Some of the basic biological data collected for the two diets are given in table 4. Effect of the bird densities, or number of birds per cage, are given in tables 5 and 6 .

The data given in Tables 5 and 6 are not of too much value in comparing the space needs of dwarfs versus non-dwarfs under the higher densities being used today. The data indicate that the cage space provided even for the non-dwarf birds was adequate or approaching adequacy. Body weight of the dwarfs was approximately 68 p. IOo, egg production 76 p. I00, egg size 90 p. IOo, daily feed consumption 7 I p. 100, feed efficiency $96 \mathrm{p}$. I00 and livability I05 p. I00 of the non-dwarf birds. The two traits of most concern to the breeder are egg production and egg size. Improvement in these will, of course, greatly enhance feed efficiency.

\section{Experiment 2 .}

For Experiment 2 heterozygous dwarf males were mated to dwarf females of the same breeding line so that both non-dwarf and dwarf progeny would have the same genetic background. The accumulation of data from other experiments had suggested that dwarf birds would respond to higher density diets than the non-dwarfs. 
TABLE 4

Effect of Diet on Performance of Dwarf Birds (Experiment I)

Effet de la ration sur les performances des oiseaux nains (expérience I)

\begin{tabular}{|c|c|c|}
\hline & \multicolumn{2}{|c|}{ Diet (P. E. cal per $\mathrm{kg} / \%$ protein) } \\
\hline & $1980 / 17$ & $1870 / 16$ \\
\hline Egg size $(g)$ & 54.9 & 54.3 \\
\hline Large eggs $(\%)$ & 53.9 & 49.6 \\
\hline Feed efficiency $(\mathrm{kg} \mathrm{fd} / \mathrm{kg}$ eggs) $\ldots \ldots$ & 2.59 & 2.64 \\
\hline Feed consumption (g/HD) . . . . . . & 70.6 & 75.8 \\
\hline
\end{tabular}

TABLE 5

Performance Data on Dwarfs vs Non-dwarf Birds (Experiment I)

Données sur les performances des naines comparées aux non-naines (Expérience $\mathrm{I}$ )

\begin{tabular}{|c|c|c|c|c|c|c|c|c|}
\hline \multirow{2}{*}{$\begin{array}{l}\text { Birds/ } \\
\text { cage }\end{array}$} & \multicolumn{2}{|c|}{$\begin{array}{l}\text { Final body } \\
\text { Wt. (g) }\end{array}$} & \multicolumn{2}{|c|}{$\operatorname{HDP}(\%)$} & \multicolumn{2}{|c|}{$\begin{array}{l}\text { Egg size } \\
(\mathrm{g})\end{array}$} & \multicolumn{2}{|c|}{$\%$ large eggs } \\
\hline & Dwarf & Non-dwarf & Dwarf & Non-dwarf & Dwarf & Non-dwarf & Dwarf & Non-dwarf \\
\hline 1 & 1126 & 1668 & 52.8 & 72.0 & 55.0 & 60.1 & 55.1 & 86.7 \\
\hline 2 & 1160 & 1664 & 55.1 & 69.1 & 54.7 & 60.2 & 52.9 & 85.6 \\
\hline 3 & 1126 & 1640 & 50.2 & 68.2 & 54.1 & 60.2 & 47.3 & 82.6 \\
\hline
\end{tabular}

\section{TABLE 6}

Daily Feed Consumption, Feed Efficiency and Livability of Dwarf vs Non-dwarf Birds (Experiment I)

Consommation journalière d'aliment, efficacité alimentaire et taux de survie des naines comparées aux non-naines (Expérience I)

\begin{tabular}{|c|c|c|c|c|c|c|}
\hline \multirow{2}{*}{$\begin{array}{c}\text { Birds/ } \\
\text { cage }\end{array}$} & \multicolumn{2}{|c|}{$\begin{array}{l}\text { Daily feed cons. } \\
(\mathrm{g})\end{array}$} & \multicolumn{2}{|c|}{$\begin{array}{c}\text { F. E. } \\
\text { (kg feed/kg eggs) }\end{array}$} & \multicolumn{2}{|c|}{ Livability $(\%)$} \\
\hline & Dwarf & Non-dwarf & Dwarf & Non-dwarf & Dwarf & Non-dwarf \\
\hline 1 & 78.7 & 111.9 & 2.71 & 2.59 & 91.3 & 83.3 \\
\hline 2 & 75.5 & 101.7 & 2.51 & 2.44 & 92.0 & 87.6 \\
\hline 3 & 71.0 & 103.1 & 2.62 & 2.51 & 88.7 & 88.8 \\
\hline
\end{tabular}


For this experiment four protein and four energy levels were used. Performance data for Experiment 2 are given in tables 7 and 8.

If averages of all protein and calorie levels are used we do not find much difference from Experiment $I$ in the ratios of performance of the dwarfs versus the nondwarfs. Body weight was 70 p. I00, egg production 80 p. I00, egg size 90 p. I00, daily feed consumption 75 p. Ioo, feed efficiency, 95 p. Ioo and livability 98 p. IOo of the non-dwarf birds. However, if tables 7 and 8 are used to compare differences

\section{TABLE 7}

Performance Data of Dwarf vs Non-Dwarf Sib Birds (Experiment 2)

Données sur les performances des naines comparées à leurs sours non-naines (Expérience 2)

\begin{tabular}{|c|c|c|c|c|c|c|c|c|}
\hline \multirow{2}{*}{$\begin{array}{l}\text { Protein level } \\
\% / C \mathrm{~kg} \text { P.E. }\end{array}$} & \multicolumn{2}{|c|}{$\begin{array}{c}\text { Final body } \\
\text { Wt. (g) }\end{array}$} & \multicolumn{2}{|c|}{$\operatorname{HDP}(\%)$} & \multicolumn{2}{|c|}{$\begin{array}{l}\text { Egg size } \\
\quad(g)\end{array}$} & \multicolumn{2}{|c|}{$\%$ large eggs } \\
\hline & Dwarf & Non-dwarf & Dwarf & Non-dwarf & Dwarf & Non-dwarf & Dwarf & Non-dwarf \\
\hline $22 / 2145$ & 1208 & 1749 & 58.5 & 63.7 & 55.9 & 62.5 & 50.4 & 92.8 \\
\hline $17 / 2035$ & !1 115 & 1679 & 50.1 & 68.7 & 55.6 & 61.7 & 50.6 & 90.6 \\
\hline $16 / 1980$ & 1254 & 1677 & 49.3 & 64.9 & 55.0 & 60.1 & 46.4 & 79.3 \\
\hline $14 / 1925$ & 1078 & 1566 & 46.8 & 59.3 & 52.7 & 60. '́ & 28.9 & 83.0 \\
\hline
\end{tabular}

TABLE 8

Daily Feed Consumption, Feed Efficiency and Livability of Dwarf vs Non-dwarf Sib Birds (Experiment 2)

Consommation journalière d'aliment, efficacité alimentaire et taux de survie des naines comparées à leurs sceurs non-naines (Expérience 2)

\begin{tabular}{|c|c|c|c|c|c|c|}
\hline \multirow{2}{*}{$\begin{array}{c}\text { Protein } \\
\text { level } \\
(\%)\end{array}$} & \multicolumn{2}{|c|}{$\begin{array}{l}\text { Daily feed cons. } \\
\qquad(g)\end{array}$} & \multicolumn{2}{|c|}{$\begin{array}{c}\text { Feed efficiency } \\
(\mathrm{kg} \text { feed/kg eggs) }\end{array}$} & \multicolumn{2}{|c|}{ Livability $(\%)$} \\
\hline & Dwarf & Non-dwarf & Dwarf & Non-dwarf & Dwarf & Non-dwarf \\
\hline 22 & 78.1 & 103.0 & 2.39 & 2.59 & 90.7 & 84.9 \\
\hline 17 & 81.9 & 109.8 & $2.9^{\prime}$ & 2.59 & 98.2 & 85.1 \\
\hline 16 & 82.6 & 112.6 & 3.04 & 2.89 & 87.4 & 89.5 \\
\hline 14 & 80.8 & 106.8 & 3.28 & 2.98 & 76.8 & 90.8 \\
\hline
\end{tabular}

in performance between treatment groups (protein and calorie levels), quite in contrast to Experiment I, a number of differences are noted. The protein/energy ratio of the 22 p. Ioo protein diet was considerably lower than the other diets which was probably reflected in a body weight and egg size of the dwarfs that was no greater than the I6 and $x 7 \mathrm{p}$. Ioo protein diets. On the other hand, for the $22 \mathrm{p}$. Ioo protein group, because part of the protein was no doubt used for energy by the non-dwarf birds 
there was an increase in body and egg size for these birds (table 7). The I4 p. Ioo protein diet was too low in protein for both dwarfs and non-dwarfs; however egg production, egg size, percent large eggs, feed efficiency and livability of the dwarfs, as expected, were more severely depressed than for the non-dwarfs. The two most encouraging observations in Experiment 2 were the significant improvement in egg production of the dwarfs receiving the $22 \mathrm{p}$. Ioo protein diet and the noticeable improvement in feed efficiency. Another interesting contrast was the livability which decreased as the protein level decreased for the dwarf birds but increased for the non-dwarfs. Daily protein consumption of the dwarfs declined from I7.I 8 grams per day for the $22 \mathrm{p}$. Ioo protein diet to a low of II.3I grams for the I4 p. Ioo diet (Table 8). For the non-dwarfs, the daily protein consumption declined from 22.66 grams per day to 14.95 grams. For the non-dwarfs, protein was severely wasted by those on the $22 \mathrm{p}$. IOo protein level but fell to less than optimum for those on the I4 p. IOO diet.

\section{Experiment 3.}

In Experiment 3 because of a limited number of available birds of the preferred type, there are two sections to the experiment. In the first section a group of dwarf birds are being compared with non-dwarfs at three densities, one, two and three birds per cage. Performance of these birds will not be reported here. The second section of the experiment consists of dwarf and non-dwarf sibs segregating from the same parent lines but housed one, two and three birds per cage of the same dimensions given for Experiment $\mathrm{I}$. The dwarfs are all receiving $22 \mathrm{p}$. Ioo protein, 2 I $45 \mathrm{ca}-$ lorie diet and the non-dwarfs are all receiving a $16.4 \mathrm{p}$. Ioo protein, 2026 calorie diet. The calories are given as productive energy per kilogram of diet.

This experiment has only progressed through four 28 -day periods. The dwarf birds laid their first eggs approximately IO-I4 days after their non-dwarf sibs. Thus, with the short experimental period currently completed the dwarfs will tend to show a lower performance score as compared with the non-dwarfs than they would after a full year of lay. Performance data for the first II 2 days are given in tables 9 and ro.

Comparison of the basic biological data from Experiment 3 with those of Experiment 2 tends to show some improvement by only one generation of selection. Body weight of the dwarfs averaged $70 \mathrm{p}$. Ioo, egg production of $87 \mathrm{p}$. Ioo, egg size 94 p. IOo, daily feed consumption 74 p. IOo, feed efficiency I Io p. IOO and livability IOO p. IOo of their non-dwarf sibs (tables 9 and Io).

If these improvements continue for the full production period of the birds in this experiment they will certainly be an encouragement to the breeder to continue his selection program with his dwarf lines or crosses.

\section{CONCLUSIONS}

The results of Experiment 3 confirm those of Experiment 2 in that the dwarf birds need a higher density diet than currently popular non-dwarf lines or crosses. They also suggest that much additional testing must be done to find the optimum 
TABLE 9

Performance Data on Dwarf vs Non-dwarf Birds (Experiment 3, 4 periods)

Performances des naines comparées aux non-naines (Expérience 3, 4 périodes)

\begin{tabular}{|c|c|c|c|c|c|c|c|c|}
\hline \multirow{2}{*}{$\begin{array}{l}\text { Birds/ } \\
\text { cage }\end{array}$} & \multicolumn{2}{|c|}{$\begin{array}{l}\text { Final body } \\
\text { Wt. (g) }\end{array}$} & \multicolumn{2}{|c|}{ HDP (\%) } & \multicolumn{2}{|c|}{$\underset{(\mathrm{g})}{\text { Egg size }}$} & \multicolumn{2}{|c|}{$\%$ large eggs } \\
\hline & Dwarf & Non-dwarf & Dwarf & Non-dwarf & Dwarf & Non-dwarf & Dwarf & Non-dwarf \\
\hline 1 & 1366 & 1853 & 66.7 & 75.3 & 54.7 & 57.5 & 46.1 & 66.7 \\
\hline 2 & 1300 & 1916 & 67.1 & 73.5 & 53.6 & 57.7 & 37.1 & 67.1 \\
\hline 3 & 1273 & 1858 & 56.0 & 69.9 & 53.4 & 57.6 & 37.5 & 64.0 \\
\hline
\end{tabular}

TABLE IO

Daily Feed Consumption, Feed Efficiency and Livability of Dwarf vs Non-dwarf Birds

(Experiment 3, 4 periods)

Consommation journalière d'aliment, efficacité alimentaire et taux de survie des naines comparées aux non-naines (Expérience 3, 4 périodes)

\begin{tabular}{|c|c|c|c|c|c|c|}
\hline \multirow{2}{*}{$\begin{array}{l}\text { Birds/ } \\
\text { cage }\end{array}$} & \multicolumn{2}{|c|}{$\begin{array}{l}\text { Daily feed cons. } \\
\qquad(\mathrm{g})\end{array}$} & \multicolumn{2}{|c|}{$\begin{array}{c}\text { F. E. } \\
\text { (kg feed/kg eggs) }\end{array}$} & \multicolumn{2}{|c|}{ Livability (\%) } \\
\hline & Dwarf & Non-dwarf & Dwarf & Non-dwarf & Dwarf & Non-dwarf \\
\hline 1 & 92.0 & 122.9 & 2.52 & 2.84 & 96.8 & 96.5 \\
\hline 2 & 85.8 & 117.1 & 2.39 & 2.76 & 96.0 & 94.8 \\
\hline 3 & 76.5 & 104.8 & 2.56 & 2.60 & 95.1 & 96.7 \\
\hline
\end{tabular}

nutrient balance for this dwarf-type bird if it is to be widely adopted for commercial laying operations. A third conclusion is that for optimum speed of adoption the geneticist and the nutritionist must work in coordination.

A close inspection of tables 9 and ro reveals a significant improvement in egg production, egg size and feed efficiency for the dwarf birds. Three birds per cage tended to reduce daily feed consumption and rate of lay. In addition to emphasis on the improvement of all other economic traits particular emphasis should be placed on research that will find ways of avoiding this depression in egg production so that higher bird densities can be used to keep down overhead cost as better houses are coming into use all over the poultry world. 


\section{RÉSUMÉ}

\section{RATIONS CONCEN'TRÉES POUR LES PONDEUSES NAINES}

L'introduction récente sur une large échelle d'un gène de nanisme lié au sexe à hérédité simple dans les programmes de test de divers sélectionneurs de souches commerciales a attiré l'attention sur la taille corporelle comme moyen potentiel d'accroître le rendement alimentaire des volailles. Les résultats de précédentes expériences à 1'Université A et $M$ du Texas ont suggéré que les pondeuses naines ont besoin d'un aliment plus concentré en éléments nutritifs que leurs sœurs non naines. Dans une expérience incluant des oiseaux non nains divisés en trois classes de poids, légers, moyens et lourds, à 20 semaines d'âge, les animaux de petite taille répondent plus que les lourds à une augmentation de la concentration de leur aliment. Un autre indice de l'importance qu'il y a à nourrir les oiseaux légers différemment de ceux dépassant le seuil minimum de poids de I 300 grammes a été obtenu antérieurement à partir d'expériences comparant les performances d'animaux éclos au printemps ou à l'automne dans un climat chaud, ainsi qu'à partir des premier et second Tests de performance "gène-environnement " du Texas.

Deux expériences comparant les performances de ponte des animaux nains et non-nains ont été réalisées. Dans la première, deux régimes (16 et $17 \mathrm{p}$. Ioo de protéines), avec le même rapport calories/protéines et un, deux ou trois oiseaux par cage de $25,4 \times 45,7 \mathrm{~cm}$ ont été comparés. Le taux protéique avait peu d'effet sur le poids corporel et la ponte par poule et par jour chez les pondeuses naines, mais la taille des œufs, le pourcentage de gros œufs et le rendement alimentaire étaient augmentés par le taux protéique le plus élevé. Les poules non-naines avaient une production d'œufs inférieure lorsque leur nombre par cage augmentait, tandis que les naines pondaient plus d'œufs lorsqu'elles étaient deux par cage.

Dans la seconde expérience, des rapports protéines/calories (p. Ioo cal/kg E. P.) de $22 / 2$ I45, $x_{7} / 2035,16 / 1980$ et $x_{4} / 1925$ étaient comparés. Une amélioration significative de la production d'œufs et du rendement alimentaire des naines recevant la ration à 22 p. Ioo de protéines était observée. La viabilité des naines décroissait avec le taux protéique, alors qu'elle allait en augmentant pour les non-naines. Avec tous les taux protéiques réunis, le rapport de la performance des naines à celle des non-naines était : pour le poids corporel, 70 p. 100; la ponte, 80 p. I00; le poids des œufs, 90 p. roo ; la consommation journalière d'aliment, 75 p. roo; le rendement alimentaire, $95 \mathrm{p}$. roo, et le taux de survie, $98 \mathrm{p}$. Ioo.

Ces résultats indiquent que les oiseaux nains requièrent une ration plus concentrée que les lignées non naines courantes. Des tests supplémentaires sont nécessaires pour déterminer l'équilibre optimum entre les composants de la ration pour ce type de naine, si ce dernier doit être employé à grande échelle commerciale pour la ponte.

\section{REFERENCES}

Hutr F. B., 1959. Sex-linked dwarfism in the fowl. J. Hered., 50, 209-22 I. 